\title{
Effects of Neonatal Blinding, Olfactory Bulbectomy and Pinealectomy on Body Weight, Food Intake and Water Drinking in Male Chickens
}

\author{
Koh-en Y amauchi, Yutaka Isshiki, Zhan-Xiang Zhou \\ and Yoshio NaKaHiro \\ Laboratory of Animal Science, Faculty of Agriculture, Kagawa \\ University, Miki-cho, Kagawa-ken, 761-07 JAPAN
}

\begin{abstract}
The effects of the combination of neonatal blinding and olfactory bulbectomy and the pinealectomy in addition to these operations on body weight, food intake and water drinking were examined in male White Leghorn chickens. Each operation and sham-operation were carried out within 24 hours after hatching and every parameter was measured from 80-day to 130-day-old. Blind anosmia had no effect on body weight but elevated food intake until 100-day-old and depressed water drinking. Pinealectomy with the blind anosmia depressed body weight, showed a tendency to increase food intake after 110-day-old and again elevated the decreased water drinking in blind anosmic chickens.

From these results, chicken pineal hormones appear to be indispensable ones for keeping a normal body weight gain, to depress the water drinking and to increase the food intake only in early stage of life. These may suggest that the chicken pineal gland has an important role also in the intakes of food and water as well as nutrient metabolic control mechanisms.
\end{abstract}

(Jpn. Poult. Sci., $27: 38-46,1990)$

Key words : neonatal blinding - pinealectomy, water drinking, body weight

\section{Introduction}

Central nervous control of water intake is maintained together by hormonal and neural factors. Arginine vasotocin (AVT), antidiuretic hormone in all non-mammalian vertebrates, is neurosecreted in the hypothalamic magnocellular supraoptic nucleus (HN) and released from the neurohypophysis to preserve body fluid. However, AVT has been identified also in the pineal gland; the bovine ${ }^{1)}$ and rat $^{2)}$ pineal glands contain such an extra-hypothalamo-neurohypophysial AVT. Besides, the pinealectomy in rats has induced a decrease in neurosecretory activity of $\mathrm{HN}^{3}$. These reports suggest that the pineal gland might function in the water intake regulation. In the previous study ${ }^{4}$, we observed a decreased water drinking in the neonatally olfactory bulbectomized chickens. Such an olfactory bulb removal (anosmia) has been reported to alter the action site of pineal hormones and make it highly sensitive to the pineal hormones ${ }^{5)}$. In rats, it is generally accepted that the pineal activity is inhibited by constant illumination but increased by constant darkness ${ }^{6)}$ and by ocular enucleation ${ }^{7)}$

(Received Jun. 7, 1989) 
(blinding). Blind anosmic rats showed a diminished food intake, resulting in lighter body weight ${ }^{8)}$. Also in chicken, functional and histological developments of the pineal gland were depressed by light even in the embryonic stage ${ }^{9)}$ and circadian rhythm of serum melatonin disappeared by neonatal pinealectomy ${ }^{10)}$. Although the avian pineal gland is phylogenetically and functionally different from that of mammals, these findings may suggest that the chicken pineal gland substances seem to influence on the water drinking and food intake. In spite of many studies on the circadian rhythm of pineal substances ${ }^{11,12}$, effects of the altered secretion activity in the pineal gland on consumptions of food and water have not been reported.

This study was designed to compare the body weight, food intake and water drinking in blind anosmic chickens with those in blind anosmic pinealectomized birds.

\section{Materials and Methods}

Sixty newly hatched male chicks of White Leghorn received the following operations and were divided into three experimental groups : group 1 was blinded by complete bilateral enucleation of eyes and olfactory bulbectomized to increase the pineal gland activity, group 2 was blinded, bulbectomized and pinealectomized, group 3 was the control which was sham-operated for removal of these organs. These chickens were operated within $24 \mathrm{hr}$ after hatching under ethyl ether anesthesia. After the operation, the newly hatched birds were returned to the brooder located in an automatic light control room ; artificial light was provided from $06: 00$ to $18: 00$ daily. Fifteen days after the operation, 5 birds in each operated group and 7 in sham-operated group, showing healthy conditions and having the same average body weight as the whole group, were selected and transferred to individual cages with free access to water and to a standard diet. Individual daily measurements of body weight, food intake and water drinking were carried out from 80-day to 130-day-old and summarized by 10-day intervals, each of which was expressed as a mean of continuous 3-day period. To estimate evaporative water loss, 2 waterers were placed in locations inaccessible to any of the experimental groups. All other birds of each group were housed in the same large cages and pooled measurements of each parameter were checked during experimental period. After termination of the experiment at 130 days of age, all birds were sacrificed by decapitation and the removals of eyes, olfactory bulbs and pineal glands were checked.

The statistical analysis for all data was performed according to Duncan's multiple range test ${ }^{13)}$.

\section{Results}

Figures 1-3 illustrate the patterns of body weight, food intake and water drinking, respectively, in the two treated and sham-operated groups from 80 - to 130-day-old. Compared with controls, body weight of blind anosmic chickens was almost similar. However, the pinealectomy in addition to the deprivation of visual and olfactory stimulations induced a significantly $(\mathrm{P}<.05)$ lighter body weight than those of other two groups at 80 - to 100-day-old and than that of blind anosmic birds at 110 - to 


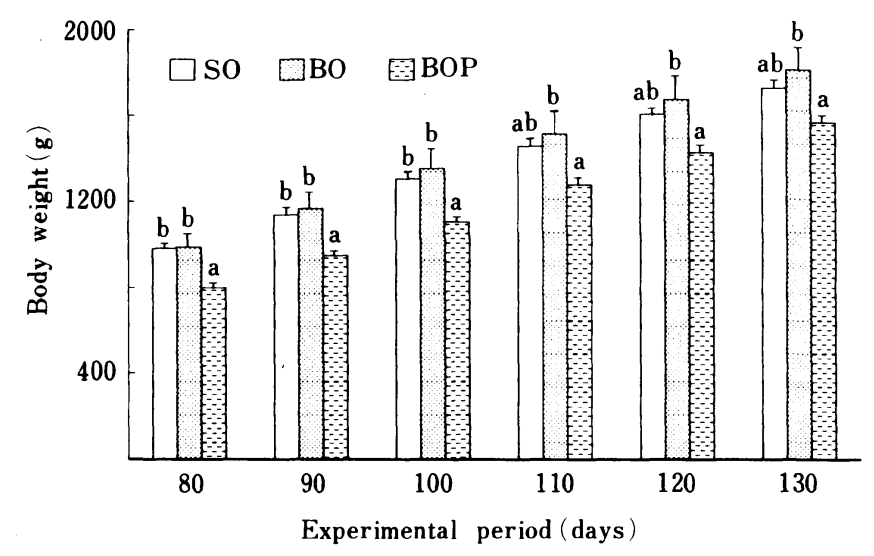

Fig. 1. Body weight of neonatally sham-operated (SO), blinded and olfactory bulbectomized (BO) and blind anosmic pinealectomized (BOP) chickens (Mean $\pm \mathrm{SE}$ for 7 birds in SO and 5 birds in $\mathrm{BO}$ and BOP).

${ }^{\mathrm{a}, \mathrm{b}}$ Means with different superscripts are significantly $(\mathrm{P}<.05)$ different among groups.

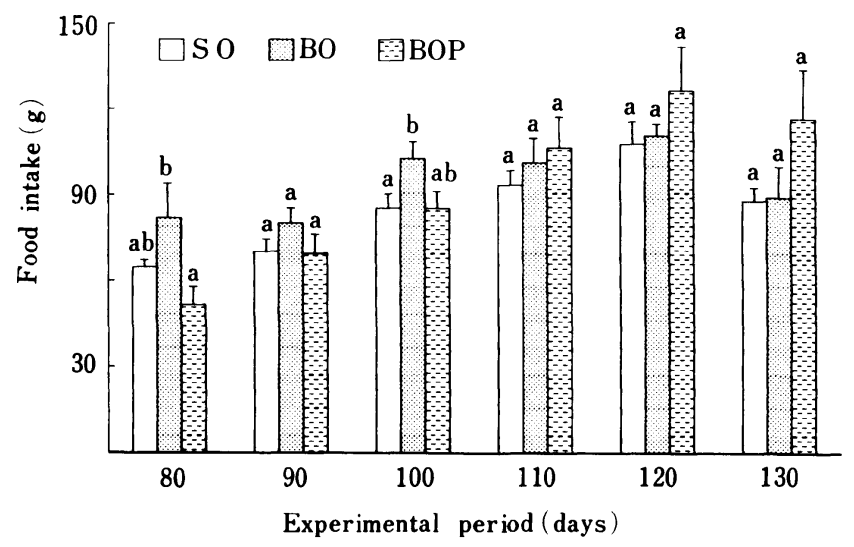

Fig. 2. Food intake (g/day/bird) of neonatally shamoperated (SO), blind anosmic (BO) and blind anosmic pinealectomized (BOP) chickens (Mean $\pm \mathrm{SE}$ for 7 birds in $\mathrm{SO}$ and 5 birds in $\mathrm{BO}$ and BOP).

${ }^{a, b}$ Means with different superscripts are significantly $(\mathrm{P}<.05)$ different among groups.

130-day-old.

Food intake of blind anosmic chickens had a tendency to increase during 80 - to 90-day-old period and showed a significant $(\mathrm{P}<.05)$ increase than the food intake of controls at 100-day-old ; while, from 110-day-old the increased food intake gradually decreased to show almost similar values with controls. Food intake of blind anosmic 


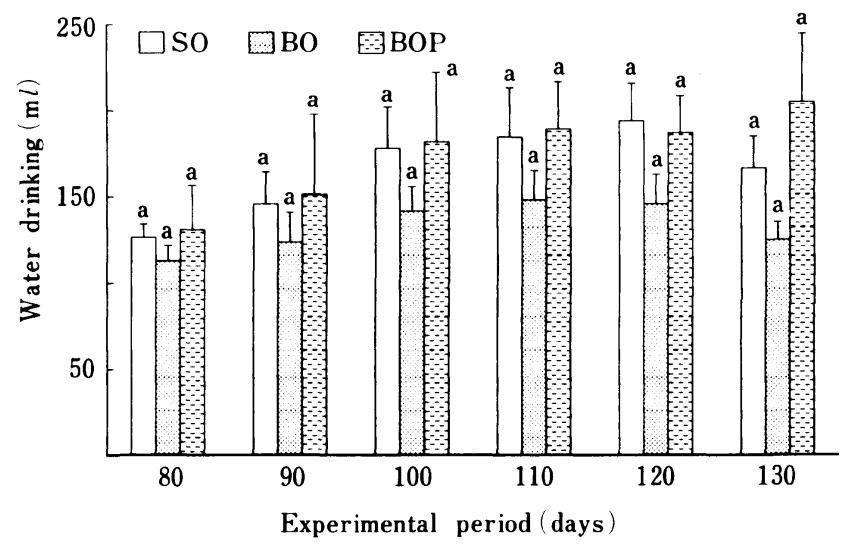

Fig. 3. Water drinking (ml/day/bird) of neonatally sham-operated (SO), blind anosmic (BO) and blind anosmic pinealectomized (BOP) chickens (Mean \pm SE for 7 birds in SO and 5 birds in $\mathrm{BO}$ and BOP).

Significant differences among groups are not observed.

pinealectomized chickens were significantly $(\mathrm{P}<.05)$ smaller than that of blind anosmic birds only at 80-day-old, while the food intake gradually increased and showed a tendency to have greater values following 110-day-old, although not statistically significant.

Water drinking of blind anosmic chickens had a tendency to show smaller values than those of controls at each day of age, although not statistically significant. This decrease of water drinking could be prevented by pinealectomy and the water drinking of pinealectomized birds increased up to the level of controls. When values of water drinking every tenth day from 80 to 130 days were added together, means of blind anosmic birds, pinealectomized and sham-operated chickens showed $133.5 \pm 5.9(\mathrm{ml} /$ bird/day ; Mean \pm SE), $175.4 \pm 11.3$ and $166.8 \pm 10.4$, respectively ; significant difference was obtained between the two operated groups $(\mathrm{P}<.05)$ as well as between blind anosmic and control groups $(\mathrm{P}<.05)$.

\section{Discussion}

Many studies on the avian pineal gland have been generally focused on the circadian rhythm of melatonin synthesis ${ }^{14)}$ and of serotonin $\mathrm{N}$-acethyltransferase activity ${ }^{11,12)}$. However, little effects of pineal hormones on the chicken nutritional physiology have been published. In the present study, an increased activity of the pineal gland by blind anosmia showed an insignificant very small increase of the body weight, while a removal of the pineal hormones induced a significant decrease of it (Fig. 1). Based on this result, it may be reasonable to consider that although the excess pineal hormones have no effects to induce a marked increase of the body weight these hormones appear to be indispensable ones for keeping a normal body weight gain 
and support the principal factors controlling the growth rate mechanisms. Actually, as the plasma concentration of chicken growth hormone is high in the early posthatching stage of rapid growth and low in the later stages of growth ${ }^{15)}$, the present newly hatched pinealectomy may lower a secretion of growth hormone in early days of life, inducing the retardation of growth in the later stage of chicken life due to the delayed growth rate in the early stage. This decreased body weight in blind anosmic pinealectomized chickens is contrary to the results mentioned in rats. Based on a growth retardation ${ }^{8,16)}$ as well as a lowered level of serum growth hormone in blind anosmic $\operatorname{rats}^{16)}$, it was speculated that the increased pineal function by light deprivation lowered the level of hypothalamic growth hormone releasing hormone, thereby depressing secretion of growth hormone ${ }^{16)}$.

With regard to the food intake, the constant trend was not observed in operated chickens. Until 100-day-old the blind anosmic operation induced an increased food intake (Fig. 2). By removal of the pineal gland, this increased food intake was significantly $(\mathrm{P}<.05)$ decreased than blind anosmic birds at 80 -day-old and showed almost same values with controls at 90 - to 100 -day-old. This result may suggest that the pineal hormones have a role to stimulate the food intake. However, following about 110-day-old the pineal hormones lost the ability to increase food intake. Reversely, the pinealectomized chickens gradually showed a tendency to have an increased food intake. When determined values of food intake in each group are expressed as a ratio to the respective body weights, the food intake of pinealectomized chickens shows a more obvious increase than the other two groups during this period (F/B in Fig. 4, $\mathrm{P}<.05)$. The disappearance of pineal ability to stimulate the food intake following 110-day-old is most likely related to the following fact. During ontogenesis, the number of pineal ganglion cells in chickens decreased, indicating the similar development with pineal phylogenetic change from sensory to secretory organs ${ }^{17)}$. In spite of the increased food intakes in blind anosmic chickens during the first half period and in pinealectomized birds during the later half failed to produce an enhancement of body weight. Therefore, the changes in the food intake due to the pineal activity seem to be unrelated to the alterations of the body weight.

The main purpose of this study was to make it clear whether water drinking is affected by the changes in secretion level of pineal substances. Blind anosmic chickens showed a constant lowered water drinking throughout the experimental period (Fig. 3). When determined values of this water drinking in each group are expressed as a ratio to their respective body weight (W/B in Fig. 4) and food intake (W/F in Fig. 4), a more obvious decrease was obtained. For the total means of each day of $\mathrm{W} / \mathrm{F}$ value, blind anosmic birds showed a significantly $(\mathrm{P}<.05)$ decreased water drinking than other two groups. As the functional and histological developments of the chicken pineal gland were depressed by light ${ }^{9)}$, the removal of chicken eyes in the present study seems to activate the pineal function. While, by the pinealectomy this decreased water drinking was reversed to show almost same levels with controls and higher values. This may suggest that the pineal hormones have a role to depress the water drinking. In the previous study ${ }^{4}$, the decreased water drinking was observed only by 

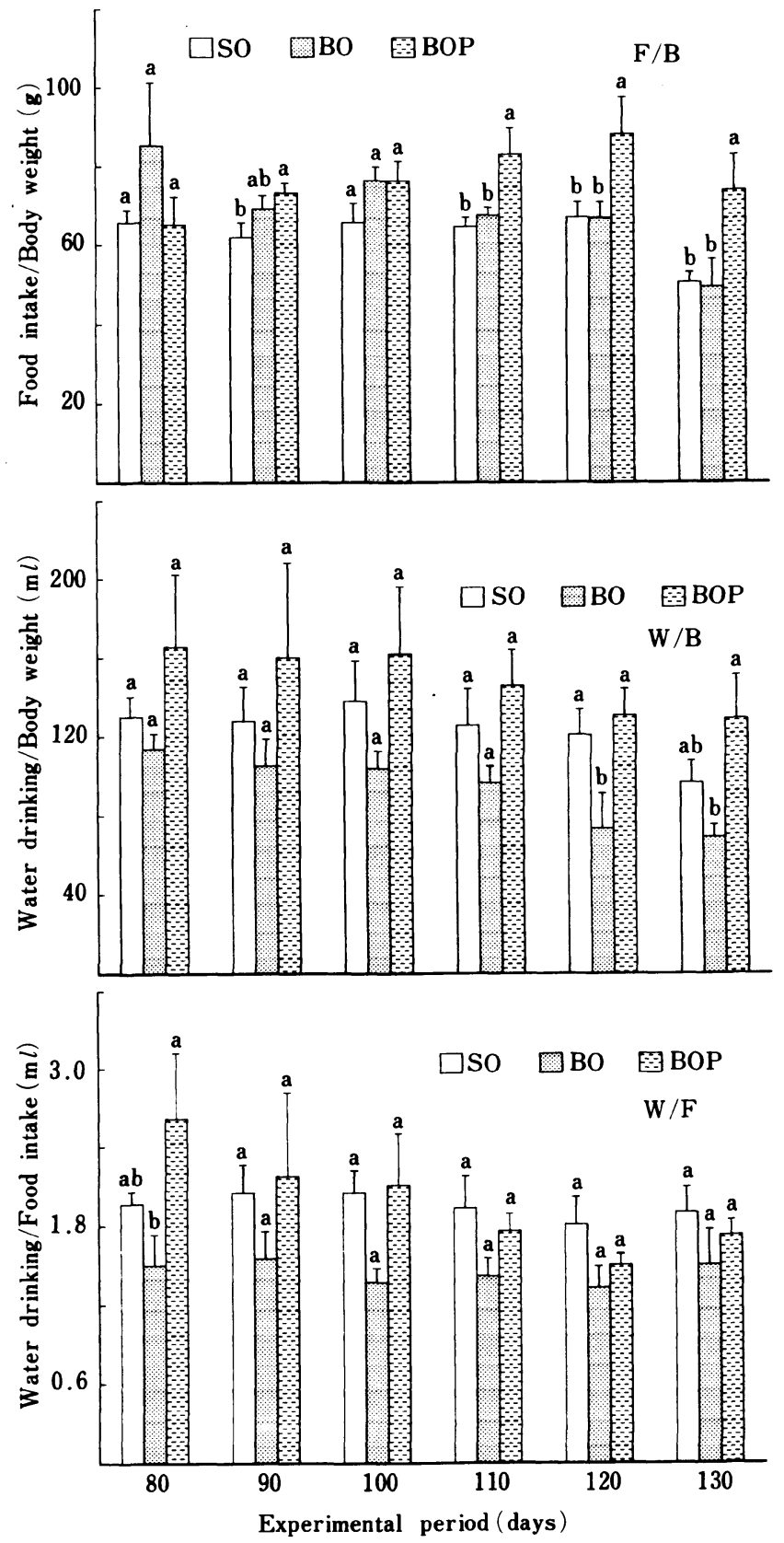

Fig. 4. Relative food intake ( $/ \mathrm{kg}$ body weight, $\mathrm{F} / \mathrm{B}$ ) and relative water drinking $(\mathrm{m} l / \mathrm{kg}$ body weight, W/B and $\mathrm{m} l / \mathrm{g}$ food intake, $\mathrm{W} / \mathrm{F}$ ) of neonatally shamoperated (SO), blind anosmic (BO) and blind anosmic pinealectomized (BOP) chickens (Mean $\pm \mathrm{SE}$ for 7 birds in $\mathrm{SO}$ and 5 birds in $\mathrm{BO}$ and $\mathrm{BOP})$.

${ }^{a, b}$ Means with different superscripts are significantly $(\mathrm{P}<.05)$ different among groups. 
the neonatal olfactory bulbectomy. As the olfactory bulb removal makes the action site of pineal hormones highly sensitive to these hormones ${ }^{5)}$, the more decreased water drinking in blind anosmic chickens than anosmic birds is thought to be reasonable results. On the other hand, in rats, an increased activity of the pineal gland containing extra-hypothalamo-neurohypophysial AVT seems to induce an elevation of secretory activity in $\mathrm{HN}$, because the removal of the pineal gland has induced a decreased activity of $\mathrm{HN}^{3}$. Besides, AVT can be secreted into third ventricular cerebrospinal fluid by ependymal cells in the bovine pineal gland ${ }^{18)}$. Although it is not clear that there is such a relationship also in birds, the fact of the decreased water drinking due to the enucleation of eyes may suggest a possibility that an increased AVT secretion by blinding efficiently maintained body fluid, thereby resulting in the decreased water drinking. On the other hand, it is reasonable to think that a lowered AVT secretion in the brain due to the pinealectomy seems to lose body fluid, drinking more water than blind anosmic birds ; especially, water drinking per body weght (W/B in Fig. 4) kept a constant higher value than other two groups throughout the experimental period. It is well recognized that the food intake value has an intimate relationship with the amount of water drinking. However, in spite of the increased food intake in blind anosmic chickens during the first half period the water drinking value does not show a correlate change. Therefore, the changes in the water drinking due to the pineal activity seem to be unrelated to the alterations of the food intake.

It is well known that the pineal gland of lower vertebrates such as fish, amphibian and reptile is a photoreceptor organ, whereas the mammalian pineal gland is a secretory $\operatorname{organ}^{9,12,17,19)}$. The avian pineal gland, which is phylogenetically an intermediate type, has two phases of photoreceptor organ ${ }^{19,20)}$ and endocrine organ ${ }^{21}$. Besides, the chicken pineal gland shows a change from sensory to secretory organs during ontogenesis ${ }^{17)}$. These functional difference between mammalian and avian pineal glands is likely one of the factors inducing the discrepancy such as the retarded growth in blind anosmic $\operatorname{rats}^{8)}$ and in our pinealectomized chickens. The increased food intake in both blind anosmic chickens during the first half of the measurement and pinealectomized birds during the later half were also contrary to the result observed in rats. The pineal substances in rats may depress the food intake because the reduction in food intake of blind anosmic rats was reversed by pineal removal ${ }^{8)}$.

Although, in this study, we did not check the serum melatonin and AVT secretion activity in the hypothalamo-neurohypophysis, the present clear changes in body weight, food intake and water drinking by blinding, anosmia as well as pinealectomy suggest a possibility that the chicken pineal gland may have an important role also in the intakes of food and water as well as the nutrient metabolic control mechanisms by affecting the hypothalamo-neurohypophysis as an endogenous organ. Further investigations are still necessary to clarify this point.

\section{References}

1) Pavel, S. (1971) Evidence for the ependymal origin of arginine vasotocin in the bovine pineal gland, Endocrinology, 89 : 613-614. 
2) Rosenbloom, A.A. and D.A. Fisher (1975) Radioimmunoassayable AVT and AVP in adult mammalian brain tissue: comparison of normal and brattleboro rats, Neuroendocrinology, $17: 354-361$.

3) DE VRIES, R.A.C. and J.A. KAPPERS (1971) Influence of the pineal gland on the neurosecretory activity of the supraoptic hypothalamic nucleus in the male rat, Neuroendocrinology, $8: 359-366$.

4) Yamauchi, K., Y. Isshiki and Y. NAKAhiro (1988) Effects of neonatal olfactory bulbectomy on the food intake, water drinking and thyroid glands in male chickens, Jpn. Poult. Sci., $25: 349-357$.

5) Reiter, R.J. and N.M. Ellison (1970) Delayed puberty in blinded anosmic female rats : role of the pineal gland, Biol. Reprod., 2 : 216-222.

6) Wurtman, R.J., J. Axelrod and L. Phillips (1963) Melatonin synthesis in the pineal gland : control by light, Science, 142 : 1071-1073.

7) Axelrod, J,, R.J. Wurtman and S.H. Snyder (1965) Control of hydroxyindole-Omethyltransferase activity in the rat pineal gland by environmental lighting, J. Biol. Chem., 240 : 949-954.

8) Reiter, R.J. (1971) Some endocrine effects of blinding and anosmia in adult male rats with observations on pineal melatonin, Endocrinology, $88: 895-900$.

9) Doi, O., Y. Kannan, S. Kato and S. Kanda (1985) Histological and histochemical studies on the pineal glands of embryonic chickens exposed to continuous light and continuous darkness, Jpn. J. Zootech. Sci., 56 : 588-597.

10) Nakamura, K., M. Torit, T. Nakamura and Y. Tanabe (1985) Photoperiodic regulation of the pineal hormone secretion in the chicken (Gallus domesticus), Jpn. Poult. Sci,, 22 : 154-155.

11) Deguchi, T. (1979) Circadian rhythm of serotonin $\mathrm{N}$-acetyltransferase activity in organ culture of chicken pineal gland, Science, 203 : 1245-1247.

12) Doi, O., T. Nakamura and Y. Tanabe (1984) Rhythmic changes in serotonin $\mathrm{N}$-acetyltransferase activity in the pineal gland of the chick exposed to different photoperiods, Jpn. J. Zootech. Sci. : 55 : 95-100.

13) Duncan, O.B. (1955) Multiple range and multiple $F$ tests, Biometrics, $11: 1-42$.

14) Yamaguchi, K.,K. Yoshino and Y. Tanabe (1987) Circadian rhythms of melatonin concentrations and contents in the plasma, pineal and retina of intact and blinded 1-2 week-old cockerels, Jpn. Poult. Sci., 24 : 383-384.

15) Scanes, C.G., S. Harvey, J.A. Marsh and D.B. King (1984) Hormones and growth in poultry, Poult. Sci., $63: 2062-2074$.

16) Shino, M., A. Arimura and E.G. Rennels (1974) Effects of blinding, olfactory bulbectomy, and pinealectomy on prolactin and growth hormone cells of the rat, with special reference to ultrastructure, Am. J. Anat., 139 : 191-208.

17) SATO, T. and K. WAKE (1981) Organizations of the sensory and sympathetic nerves in the avian pineal organs, Jikeikai Med. J., 28 (Suppl. 1) : 7-12.

18) Pavel, S. (1971) Evidence for the ependymal origin of arginine vasotocin in the bovine pineal gland, Endocrinology, 89 : 613-614.

19) Deguchi, T. (1981) Rhodopsin-like photosensitivity of isolated chicken pineal gland, Nature, 290 : 706-707.

20) Underwood, H. and G. Groos (1982) Vertebrate circadian rhythms: retinal and extraretinal photoreception, Experientia, 38 : 1013-1021.

21) Takahashi, J.S.,H. Hamm and M. Menaker (1980) Circadian rhythms of melatonin release from individual superfused chicken pineal gland in vitro, Proc. Natl Acad. Sci. USA, 77 : 2319-2322. 


\title{
初生雊における眼球, 嗅球および松果体除去が 体重，摂食および飲水に及ぼす影響
}

\author{
山内高円 - 一色 泰 - 周 占 祥 - 中廣義雄 \\ 香川大学農学部, 香川県 761-07
}

\begin{abstract}
粰化後 24 時間以内の白色レグホーン種の雄雊を用い て眼球・嗅球除去 (松果体機能六進) および眼球・嗅球 ・松果体除去手術を施し, 体重, 摃食量および飲水量に 及ぼす影響を術後 80 日より 130 日まで測定した。

その結果, 擬似手術鵎と比較して眼球 - 嗅球除去鷄で は体重の変化は認められなかったが，100日齢までの摄 食量の增加や全測定期間中飲水量の減少が観察された。 眼球・嗅球・松果体除去鵎では, 体重の減少, 110 日齢 以降の摂食量の增加ならびに眼球・嗅球除去により減少
\end{abstract}

\section{した飲水量の再増加が観察された。}

以上の結果から, 鶏の松果体ホルモンは正常な体重維 持に不可欠なホルモンであり, 飲水量の減少や幼若期の 摄食量の增加を誘引する作用をむつものと思われ，飼料 や水の摄取および栄養素代謝調節機構にも重要な役割を 果しているものと示唆される。

（家禽会誌, $27: 38-46,1990)$

キーワード: 初生踓, 眼球・嗅球・松果体除去, 飲水 量, 增体, 飼料摂取量 